\title{
Combined effects of temperature and prey (Brachionus angularis) density on life-table demography and population growth of Asplanchna brightwelli (Rotifera)
}

\author{
Ling Pan, Yi-Long Xi* ${ }^{*}$, Hong-Yuan Cao, Bin Peng and Jin-Xia Wang \\ Provincial Laboratory for Conservation and Utilization of Important Biological Resource in Anhui, College of Life Sciences, \\ Anhui Normal University, Wuhu 241000, Anhui, P. R. China
}

Received 6 July 2014; Accepted 29 August 2014

\begin{abstract}
Predator-prey interactions play major and direct roles in the structuring of zooplankton communities. Asplanchna usually predates ciliates, rotifers, cladocerans and sometimes even copepods, its predation may drive not only the ecological, but also the evolutionary dynamics of prey populations. In the present study, the life-table demography and the population growth of Asplanchna brightwelli were investigated at four temperatures $\left(16,20,24\right.$ and $\left.28^{\circ} \mathrm{C}\right)$ using Brachionus angularis as prey at four densities $\left(10,20,30\right.$ and 40 ind. $\left.\mathrm{mL}^{-1}\right)$. The results showed that temperature affected significantly all the life-table demographic parameters (age-specific survivorship and fecundity, average lifespan, life expectancy at hatching, generation time, net reproductive rate and intrinsic rate of population increase) and the population growth rate obtained from the population growth studies, prey density affected the generation time, the net reproductive rate, the intrinsic rate of population increase and the population growth rate, and the interaction between temperature and prey density affected the generation time and the population growth rate. Both the average lifespan and the life expectancy at hatching were the longest at $16^{\circ} \mathrm{C}$, the generation times were longer at lower temperatures $\left(16\right.$ and $\left.20^{\circ} \mathrm{C}\right)$ and higher prey densities $(30$ and 40 ind. $\mathrm{mL}^{-1}$ ), the net reproductive rates were higher at lower temperatures $\left(16\right.$ and $\left.20^{\circ} \mathrm{C}\right)$ and $20-40$ ind. $\mathrm{mL}^{-1}$ of $B$. angularis, and the population growth rates were higher at $20^{\circ} \mathrm{C}$ under $20-40$ ind. $\mathrm{mL}^{-1}$ of B. angularis.
\end{abstract}

Key words: Asplanchna brightwelli / life history / population growth / temperature / Brachionus angularis density

\section{Introduction}

Zooplankton in freshwater is mainly composed of protozoans, rotifers, cladocerans and copepods (Seoánes and Aguado, 1995), among which rotifers are noteworthy for their important role in the transfer of energy from primary producers to secondary and tertiary consumers in aquatic food webs. Most genera of rotifers are herbivorous, feeding on phytoplankton, whereas others are carnivorous feeding on ciliates, other rotifers and small crustaceans. Among all the carnivorous rotifers, most members of the rotifer genus Asplanchna Gosse are predatory, and their diet predominantly comprises a variety of prey species that include ciliates, rotifers, cladocerans and sometimes even copepods (Ejsmont-Karabin, 1974; Guiset, 1977; Williamson, 1983; Arndt, 1993). Although

*Corresponding author: ylxi1965@126.com most crustacean zooplankton may escape predation by Asplanchna due to their large size, rotifers are more susceptible (Williamson, 1983). Therefore, Asplanchnacontrolled changes in the abundance and diversity of herbivorous rotifers can be significant (Pourriot, 1977). As an important selective agent, predation by Asplanchna may drive not only the ecological but also the evolutionary dynamics of prey populations.

Asplanchna has been used as an important model organism for the laboratory study of predation feeding on a variety of prey (Williamson, 1983). Much literature is available on the food and feeding habits of Asplanchna, both from field and laboratory studies (reviewed in Dumont, 1977; Pourriot, 1977; Williamson, 1983; Arndt, 1993; Sarma, 1993; Conde-Porcuna and Sarma, 1995; Iyer and Rao, 1996; Nandini and Sarma, 1999; Nandini et al., 2003; Sarma et al., 2011). Although there are some data on the life-table demography and the population growth rate 
of Asplanchna as a function of prey levels (e.g., Urabe, 1992; Dumont and Sarma, 1995; Conde- Porcuna and Declerck, 1998; Sarma et al., 1998, 2002a, 2003; Nandini and Sarma, 1999, 2000; Nandini et al., 2003), the combined effects of temperature and the prey level are inadequately studied (Verdone-Smith and Enesco, 1982).

Among the members of the genus Asplanchna, A. brightwelli Gosse is a cosmopolitan species, feeding on rotifer genera such as Anuraeopsis Lauterborn, Brachionus Pallas and Keratella Bory de St. Vincent (Urabe, 1992; Conde- Porcuna and Declerck, 1998; Sarma et al., 1998). $B$. angularis Gosse is also a cosmopolitan species, and lacks morphological defences against Asplanchna predation. However, in subtropical shallow lakes, the population density of $B$. angularis is not controlled by Asplanchna (Wen et al., 2011a, 2011b). Therefore, investigating the combined effects of temperature and prey (B. angularis) density on life-table demography and population growth of $A$. brightwelli could be helpful for the interpretation of seasonal changes of these zooplankton species under field conditions.

The developmental rate of poikilothermic animals increases with increasing temperature, and it is enhanced at suitable food levels. In the present study, the combined effects of four levels of temperature and prey level on the life-table demographic parameters and the population growth rate of $A$. brightwelli were investigated not only to find out the optimal condition for population growth, but also to test the hypothesis that at all the tested prey levels, both the survival and the generation time of $A$. brightwelli decrease with increasing temperature.

As usual, an organism utilizes its intake energy for survival, growth and reproduction. The relative allocation of intake energy to reproduction is obviously a function of the quantity of food available and consumed, and related with temperature because of its influence on the energetic costs of metabolism. Therefore, the present study will test another hypothesis that whether a prey level is suitable for the reproduction of $A$. brightwelli depends on the temperature and the negative effect of the unsuitable food level becomes greater with increasing temperature.

\section{Material and methods}

The predatory rotifer A. brightwelli (body length: $900 \pm 50 \mu \mathrm{m})$ was isolated from Lake Fengming (Wuhu City, Anhui Province, China) in October, 2013. Four clonal populations were established with parthenogetic females individually, and were respectively maintained in $500 \mathrm{~mL}$ beakers with $B$. angularis (body length: $150 \pm 25 \mu \mathrm{m}$ ) being exclusive food (at a density of 30 ind. $\mathrm{mL}^{-1}$ ). B. angularis itself was mass cultured from a single clone using alga Scenedesmus obliquus (Turp.) Kütz at $1.0 \times 10^{6}$ cells. $\mathrm{mL}^{-1}$ as food. The alga was grown in semi-continuous culture using $\mathrm{HB}-4$ medium that contained $200 \mathrm{mg}\left(\mathrm{NH}_{4}\right)_{2} \mathrm{SO}_{4}, 15 \mathrm{mg} \mathrm{K}_{2} \mathrm{HPO}_{4}, 15 \mathrm{mg} \mathrm{CaCl}$, $80 \mathrm{mg} \mathrm{MgSO}{ }_{4} \cdot 7 \mathrm{H}_{2} \mathrm{O}, 100 \mathrm{mg} \mathrm{NaHCO} 3,25 \mathrm{mg} \mathrm{KCl}$ and $22.5 \mathrm{mg} \mathrm{FeCl} \cdot 6 \mathrm{H}_{2} \mathrm{O}$ per $1000 \mathrm{~mL}$ of double-distilled water (Li et al., 1959). Algal cells were harvested in the exponential phase of growth, centrifuged at $3000 \mathrm{rpm}$ for 5 min, resuspended in distilled water and stored at $4{ }^{\circ} \mathrm{C}$ in a refrigerator for maintenance of rotifer cultures and experiments. Algal cell concentration was measured with a haemocytometer.

For routine maintenance of zooplankton cultures at $25 \pm 1{ }^{\circ} \mathrm{C}$ as well as for conducting experiments we used moderate hard water which contained $100 \mathrm{mg} \mathrm{KNO}$, $40 \mathrm{mg} \mathrm{K}_{2} \mathrm{HPO}_{4}, 62 \mathrm{mg} \mathrm{MgSO}_{4} \cdot 7 \mathrm{H}_{2} \mathrm{O}$ and $144 \mathrm{mg}$ $\mathrm{Ca}\left(\mathrm{NO}_{3}\right)_{2} \cdot 4 \mathrm{H}_{2} \mathrm{O}$ in $1000 \mathrm{~mL}$ of $0.002 \mathrm{M} \mathrm{NaH}{ }_{2} \mathrm{PO}_{4}$ $\mathrm{Na}_{2} \mathrm{HPO}_{4}$ buffer ( $\mathrm{pH}$ 7.3) prepared in distilled water (Gilbert, 1963). Mass cultures of both A. brightwelli and $B$. angularis were changed with fresh moderate hard water every alternate day. In the cultures we usually obtained A. brightwelli at a density of 1 ind. $\mathrm{mL}^{-1}$ and $B$. angularis at 50 ind. $\mathrm{mL}^{-1}$. Prior to starting the experiments, about 1 $\mathrm{L}$ of $A$. brightwelli and $2 \mathrm{~L}$ of $B$. angularis from cultures were separately maintained for about 2 weeks at four chosen temperatures $\left(16,20,24\right.$ and $\left.28^{\circ} \mathrm{C}\right)$. Between 14 and $30^{\circ} \mathrm{C}$, A. brightwelli occurred in subtropical shallow lakes such as Lake Fengming (Xie., 2014).

For life-table experiments, we used four replicate (four clones) beakers with $15 \mathrm{~mL}$ medium of $25 \mathrm{~mL}$ capacity. Four $\left(10,20,30\right.$ and 40 . ind. $\left.\mathrm{mL}^{-1}\right)$ densities of $B$. angularis were offered on the basis of preliminary experiments. Prey density was estimated on aliquot samples from mass cultures. Thus for life-table demography of A. brightwelli on B. angularis, we used 64 test beakers (four prey densities $\times$ four temperatures $\times$ four replicates). Into each test beaker we introduced ten neonates $(<4 \mathrm{~h}$ old $)$ of A. brightwelli and desired density of prey. The experiments were conducted at four temperatures with continuous but diffused illumination. Observation was made at 12-h intervals, although food was added at every $24-\mathrm{h}$ period. We counted and discarded the number of neonates born and dead adults. The surviving adults were transferred to fresh beakers containing appropriate prey density at corresponding temperature. The experiments were terminated when the last individual of each cohort died. Standard life tables were constructed following Poole (1974). The variables analyzed included age-specific survivorship and fecundity, average lifespan (LS), life expectancy at hatching $\left(e_{0}\right)$, generation time $(T)$, net reproductive rate $\left(R_{0}\right)$ and intrinsic rate of population increase $\left(r_{\mathrm{m}}\right)$, using standard formulae according to Krebs (1985) and Pianka (1988):

$$
\begin{aligned}
& \text { Net reproductive rate }\left(R_{0}\right)=\sum_{0}^{\infty} l_{x} m_{x} \\
& \text { Generation time }(T)=\sum l_{x} m_{x} x / R_{0}
\end{aligned}
$$

Intrinsic rate of population increase $(r)$, first an approximation using:

$$
r=\ln R_{0} / T
$$

For final calculation, we solved the equation:

$$
\sum_{X=0}^{\infty} \mathrm{e}^{-r x} l_{x} m_{x}=1
$$




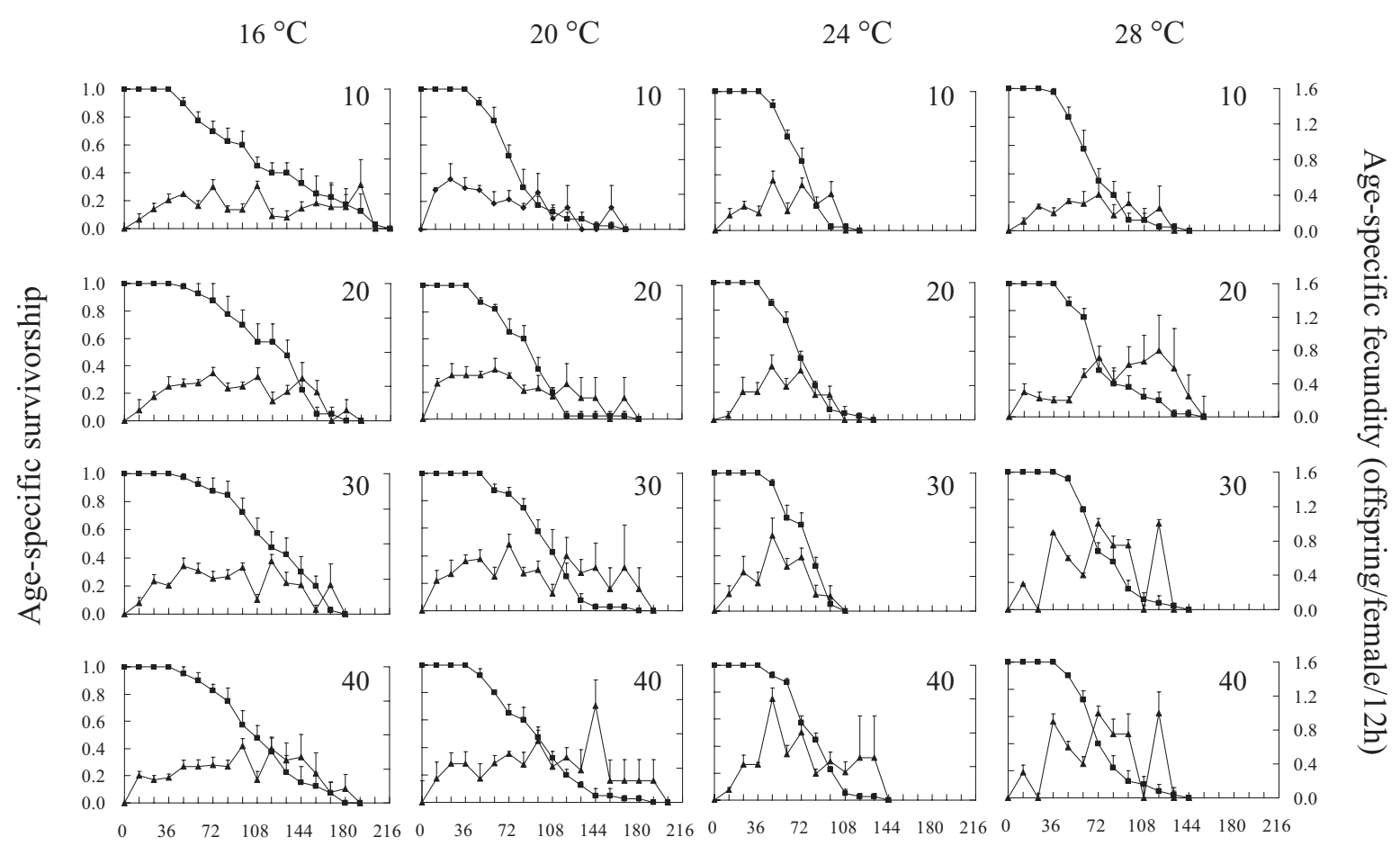

Time (h)

\begin{abstract}
survivorship
- $\Delta$ - fecundity

Fig. 1. Survivorship and fecundity of Asplanchna brightwelli cultured at four temperatures and prey (B. angularis, ind.mL ${ }^{-1}$ ) densities (mean $\pm \mathrm{SE})$.
\end{abstract}

For population growth experiments, we used the same experimental design as used for the life-table experiments. Following initiation of the experiments, we estimated daily the density of $A$. brightwelli from each replicate using whole counts. The living individuals of $A$. brightwelli were then transferred to new beakers with the chosen quantity of medium, food density and temperature. The population growth experiments were terminated after 16 days when the predator populations in most replicates began to decline. Based on the data collected, we obtained the rate of population increase $(r)$ using the exponential equation after appropriate curve fitting (Poole, 1974):

$$
r=\left(\ln N_{t}-\ln N_{0}\right) / t
$$

All data were tested for normality using the one-sample Kolmogrov-Smirnov procedure. Homogeneity of variances was checked using Levene's test. One-way analysis of variance (ANOVA) was conducted to identify the significant effect of temperature at each prey density as well as prey density at each temperature on each of the life history variables, and two-way ANOVA was conducted to identify significant effects of temperature, prey density and their interaction on each of the life history variables. Multiple comparisons were conducted using least significant difference (LSD) tests.

\section{Results}

\section{Life table demography}

The age-specific survivorship of $A$. brightwelli fed $B$. angularis in relation to prey density and temperature are presented in Figure 1. There was no mortality in the first 1.5 days but a high death in the next 2.5 days, the survivorship curves began to show steep mortality, especially at higher temperatures $\left(24\right.$ and $\left.28^{\circ} \mathrm{C}\right)$. In general, regardless of prey density, the survivorships at 16 and $20^{\circ} \mathrm{C}$ were significantly higher than at 24 and $28^{\circ} \mathrm{C}$ $(P<0.01)$. Regardless of temperature, prey density did not significantly affect the survivorship.

The age-specific fecundity curves of $A$. brightwelli fed $B$. angularis showed the hump-shaped sawtooth-like pattern. In general, the duration of reproductive period decreased with increasing temperature, except for those at $24^{\circ} \mathrm{C}$ with $10-30$ ind. $\mathrm{mL}^{-1}$. The age-specific fecundity increased with increasing temperature, except for that at $28^{\circ} \mathrm{C}$ with 10 ind. $\mathrm{mL}^{-1}$ (Fig. 1).

The main life-table demographic parameters of $A$. brightwelli fed $B$. angularis in relation to prey density and temperature are presented in Table 1. Temperature affected significantly both the average lifespan and the life expectancy at hatching $(P<0.01$, two-way ANOVA; Table 2), but prey density and the interaction between 
Table 1. Effects of prey density (B. angularis, ind. $\mathrm{mL}^{-1}$ ) on life-table demography and population growth of A. brightwelli cultured at four temperatures (mean $\pm \mathrm{SE})$.

\begin{tabular}{|c|c|c|c|c|c|}
\hline \multirow[b]{2}{*}{ Parameters } & \multirow[b]{2}{*}{ Prey density } & \multicolumn{4}{|c|}{ Temperature } \\
\hline & & $16^{\circ} \mathrm{C}$ & $20^{\circ} \mathrm{C}$ & $24^{\circ} \mathrm{C}$ & $28^{\circ} \mathrm{C}$ \\
\hline \multicolumn{6}{|l|}{ Life-table demography } \\
\hline \multirow[t]{4}{*}{ Average lifespan (h) } & 10 & $101.7 \pm 12.6^{\mathrm{A}}$ & $66.0 \pm 4.6^{\mathrm{aB}}$ & $57.6 \pm 2.8^{\mathrm{aB}}$ & $55.8 \pm 5.8^{\mathrm{B}}$ \\
\hline & 20 & $104.4 \pm 10.8^{\mathrm{A}}$ & $73.8 \pm 4.9^{\mathrm{aB}}$ & $59.1 \pm 1.6^{\mathrm{aB}}$ & $63.6 \pm 3.7^{\mathrm{B}}$ \\
\hline & 30 & $106.2 \pm 9.5^{\mathrm{A}}$ & $88.5 \pm 3.3^{\mathrm{bB}}$ & $61.2 \pm 2.9^{\mathrm{abC}}$ & $63.0 \pm 2.7^{\mathrm{C}}$ \\
\hline & 40 & $95.1 \pm 7.0^{\mathrm{A}}$ & $77.1 \pm 1.6^{\mathrm{abB}}$ & $67.8 \pm 1.9^{\mathrm{bBC}}$ & $60.6 \pm 3.5^{\mathrm{C}}$ \\
\hline \multirow[t]{4}{*}{ Life expectancy at hatching (h) } & 10 & $94.8 \pm 10.5^{\mathrm{A}}$ & $65.0 \pm 3.8^{\mathrm{aB}}$ & $58.0 \pm 2.3^{\mathrm{aB}}$ & $56.5 \pm 4.9^{\mathrm{B}}$ \\
\hline & 20 & $97.0 \pm 9.0^{\mathrm{A}}$ & $71.5 \pm 4.1^{\mathrm{acB}}$ & $59.3 \pm 1.3^{\mathrm{aB}}$ & $63.0 \pm 3.1^{\mathrm{B}}$ \\
\hline & 30 & $98.5 \pm 7.9^{\mathrm{A}}$ & $83.8 \pm 2.8^{\mathrm{bB}}$ & $61.0 \pm 2.4^{\mathrm{abC}}$ & $62.5 \pm 2.3^{\mathrm{C}}$ \\
\hline & 40 & $89.3 \pm 5.8^{\mathrm{A}}$ & $77.5 \pm 4.0^{\mathrm{bcAB}}$ & $66.5 \pm 1.6^{\mathrm{bBC}}$ & $60.5 \pm 2.9^{\mathrm{C}}$ \\
\hline \multirow[t]{4}{*}{ Generation time $(\mathrm{h})$} & 10 & $70.7 \pm 3.3^{\mathrm{A}}$ & $41.5 \pm 2.0^{\mathrm{aB}}$ & $45.7 \pm 3.3^{\mathrm{aB}}$ & $45.7 \pm 4.8^{\mathrm{B}}$ \\
\hline & 20 & $69.5 \pm 3.1^{\mathrm{A}}$ & $49.4 \pm 3.1^{\mathrm{abBC}}$ & $48.4 \pm 2.9^{\mathrm{aC}}$ & $60.7 \pm 5.7^{\mathrm{AB}}$ \\
\hline & 30 & $70.2 \pm 4.1^{\mathrm{A}}$ & $60.9 \pm 4.5^{\mathrm{bcAB}}$ & $46.4 \pm 3.6^{\mathrm{aC}}$ & $52.0 \pm 2.5^{\mathrm{BC}}$ \\
\hline & 40 & $67.5 \pm 3.9^{\mathrm{A}}$ & $62.4 \pm 5.3^{\mathrm{cAB}}$ & $52.2 \pm 1.5^{\mathrm{aBC}}$ & $50.1 \pm 3.5^{\mathrm{C}}$ \\
\hline \multirow[t]{4}{*}{ Net reproductive rate } & 10 & $2.3 \pm 0.2^{\mathrm{A}}$ & $2.5 \pm 0.3^{\mathrm{A}}$ & $1.7 \pm 0.2^{\mathrm{aB}}$ & $1.2 \pm 0.1^{\mathrm{aB}}$ \\
\hline & 20 & $3.3 \pm 0.5^{\mathrm{A}}$ & $3.3 \pm 0.4^{\mathrm{A}}$ & $1.8 \pm 0.2^{\mathrm{abB}}$ & $2.2 \pm 0.2^{\mathrm{bB}}$ \\
\hline & 30 & $3.6 \pm 0.3^{\mathrm{AC}}$ & $4.0 \pm 0.3^{\mathrm{AD}}$ & $2.6 \pm 0.3^{\mathrm{bcB}}$ & $2.8 \pm 0.2^{\mathrm{bBC}}$ \\
\hline & 40 & $3.4 \pm 0.5$ & $3.1 \pm 0.4$ & $3.4 \pm 0.3^{\mathrm{c}}$ & $2.3 \pm 0.3^{\mathrm{b}}$ \\
\hline \multirow{4}{*}{$\begin{array}{l}\text { Intrinsic rate of } \\
\text { population increase }\left(\mathrm{day}^{-1}\right)\end{array}$} & 10 & $0.336 \pm 0.048^{\mathrm{B}}$ & $0.648 \pm 0.096^{\mathrm{A}}$ & $0.288 \pm 0.072^{\mathrm{aBC}}$ & $0.096 \pm 0.024^{\mathrm{aC}}$ \\
\hline & 20 & $0.480 \pm 0.096^{\mathrm{AB}}$ & $0.720 \pm 0.096^{\mathrm{A}}$ & $0.312 \pm 0.096^{\mathrm{abB}}$ & $0.360 \pm 0.048^{\mathrm{bB}}$ \\
\hline & 30 & $0.528 \pm 0.048$ & $0.720 \pm 0.096$ & $0.552 \pm 0.096^{\mathrm{bc}}$ & $0.528 \pm 0.048^{c}$ \\
\hline & 40 & $0.521 \pm 0.050$ & $0.552 \pm 0.096$ & $0.624 \pm 0.072^{\mathrm{c}}$ & $0.408 \pm 0.072^{\mathrm{bc}}$ \\
\hline \multicolumn{6}{|l|}{ Population growth } \\
\hline \multirow[t]{4}{*}{ Rate of population increase $\left(\mathrm{day}^{-1}\right)$} & 10 & $0.057 \pm 0.066$ & $0.207 \pm 0.039$ & $0.054 \pm 0.034^{\mathrm{a}}$ & $0.049 \pm 0.021^{\mathrm{a}}$ \\
\hline & 20 & $0.269 \pm 0.053^{\mathrm{A}}$ & $0.309 \pm 0.043^{\mathrm{A}}$ & $0.125 \pm 0.037^{\mathrm{aB}}$ & $0.092 \pm 0.023^{\mathrm{aB}}$ \\
\hline & 30 & $0.155 \pm 0.017^{\mathrm{BC}}$ & $0.226 \pm 0.032^{\mathrm{B}}$ & $0.325 \pm 0.030^{\mathrm{bA}}$ & $0.135 \pm 0.016^{\mathrm{abC}}$ \\
\hline & 40 & $0.185 \pm 0.050$ & $0.264 \pm 0.028$ & $0.273 \pm 0.054^{\mathrm{b}}$ & $0.185 \pm 0.045^{\mathrm{b}}$ \\
\hline
\end{tabular}

*Lowercase and capital letters indicate sample means that are similar (same letter) or different (different letter) for each variable among the four prey densities and temperatures, respectively (LSD multiple comparison test).

temperature and prey density did not affect them $(P>0.05)$. Both the average lifespan and the life expectancy at hatching was the longest at $16^{\circ} \mathrm{C}$ and the shortest at 24 and $28^{\circ} \mathrm{C}$ (Table 1 ).

Both temperature and prey density, and their interaction had significant effects on the generation time $(P<0.05$, Table 2$)$. The generation times were longer at lower temperatures $\left(16\right.$ and $\left.20^{\circ} \mathrm{C}\right)$ and higher prey densities (30 and 40 ind. $\mathrm{mL}^{-1}$ ) (Table 1).

Both temperature and prey density had significant effects on the net reproductive rate and the intrinsic rate of population increase $(P<0.01$, Table 2$)$, but their interaction did not affect them $(P>0.05)$. The net reproductive rates were significantly higher at lower temperatures (16 and $20^{\circ} \mathrm{C}$ ) than at higher temperatures $\left(24\right.$ and $\left.28^{\circ} \mathrm{C}\right)$. The intrinsic rate of population increase was the highest at $20{ }^{\circ} \mathrm{C}$. The intrinsic rate of population increase was higher at $16^{\circ} \mathrm{C}$ than at $28^{\circ} \mathrm{C}$, but both of them were similar to that at $24^{\circ} \mathrm{C}$. Both the net reproductive rate and the intrinsic rate of population increase increased with prey density increasing from 10 to 30 ind. $\mathrm{mL}^{-1}$, but those at 40 ind. $\mathrm{mL}^{-1}$ were similar to those at 20 and 30 ind. $\mathrm{mL}^{-1}$ (Table 1).

\section{Population growth}

At all the four temperatures, the maximum density of $A$. brightwelli increased with increasing availability of
B. angularis in the medium (Fig. 2). Both temperature and prey density, and their interaction had significant effects on the population growth rate of $A$. brightwelli $\left(P<0.05\right.$, Table 2). At $20^{\circ} \mathrm{C}$ and $20-40$ ind.mL ${ }^{-1}$ of $B$. angularis, $A$. brightwelli had higher population growth rates (Table 1).

\section{Discussion}

The effect of prey density on survival and development of Asplanchna species depended on prey species. The survival of $A$. girodi De Guerne was not significantly affected by the density of both $B$. havanaensis Rousselet (densities ranged from 1 to 8 ind. $\mathrm{mL}^{-1}$ ) and Anuraeopsis fissa Gosse (250-2000 ind. $\left.\mathrm{mL}^{-1}\right)$, but the average lifespan of $A$. girodi fed $B$. calyciflorus Pallas at 1 ind. $\mathrm{mL}^{-1}$ was longer than that at $2-8$ ind. $\mathrm{mL}^{-1}$. The generation time of $A$. girodi decreased with increasing prey (B. havanaensis or $B$. calyciflorus) density, but increased with increasing A. fissa density (Dumont and Sarma, 1995; Sarma et al., 2003). In the present study, we found that the effect of prey density on survival and development of $A$. brightwelli also depended on temperature. At 16 and $28^{\circ} \mathrm{C}$, and 16,24 and $28^{\circ} \mathrm{C}$, the average lifespan and the life expectancy at hatching, and the generation time of $A$. brightwelli were not affected by $B$. angularis density, respectively. However, at $20{ }^{\circ} \mathrm{C}$, both the average lifespan and the life expectancy 
Table 2. Results of two-way ANOVA performed for different life-table demographic and population growth parameters of A. brightwelli cultured at four temperatures and prey (B. angularis) densities.

\begin{tabular}{|c|c|c|c|c|}
\hline Parameters and sources & $M S$ & $S S$ & d.f. & $F$ \\
\hline \multicolumn{5}{|l|}{ Life-table demography } \\
\hline \multicolumn{5}{|l|}{ Average lifespan } \\
\hline Temperature & 5920.12 & 17760.35 & 3 & $42.12^{* *}$ \\
\hline Prey density & 238.34 & 715.01 & 3 & $1.70^{\mathrm{ns}}$ \\
\hline Temperature $\times$ prey density & 112.19 & 1009.73 & 9 & $0.80^{\mathrm{ns}}$ \\
\hline Error & 140.56 & 6746.67 & 48 & \\
\hline \multicolumn{5}{|l|}{ Life expectancy at hatching } \\
\hline Temperature & 4123.02 & 12369.06 & 3 & $40.74^{* *}$ \\
\hline Prey density & 168.56 & 505.69 & 3 & $1.67^{\mathrm{ns}}$ \\
\hline Temperature $\times$ prey density & 82.24 & 740.19 & 9 & $0.81^{\mathrm{ns}}$ \\
\hline Error & 101.21 & 4858.00 & 48 & \\
\hline \multicolumn{5}{|l|}{ Generation time } \\
\hline Temperature & 1404.39 & 4213.17 & 3 & $25.16^{* *}$ \\
\hline Prey density & 176.75 & 530.26 & 3 & $3.17 *$ \\
\hline Temperature $\times$ prey density & 139.94 & 1259.49 & 9 & $2.51 *$ \\
\hline Error & 55.81 & 2679.07 & 48 & \\
\hline \multicolumn{5}{|l|}{ Net reproductive rate } \\
\hline Temperature & 5.15 & 15.45 & 3 & $13.11^{* *}$ \\
\hline Prey density & 5.35 & 16.04 & 3 & $13.60^{* *}$ \\
\hline Temperature $\times$ prey density & 0.49 & 4.44 & 9 & $1.26^{\mathrm{ns}}$ \\
\hline Error & 0.39 & 18.86 & 48 & \\
\hline \multicolumn{5}{|c|}{ Intrinsic rate of population increase } \\
\hline Temperature & 0.00 & 0.001 & 3 & $12.11^{* *}$ \\
\hline Prey density & 0.00 & 0.001 & 3 & $7.99^{* *}$ \\
\hline Temperature $\times$ prey density & $7.20 \times 10^{-5}$ & 0.001 & 9 & $1.91^{\mathrm{ns}}$ \\
\hline Error & $3.78 \times 10^{-5}$ & 0.002 & 48 & \\
\hline \multicolumn{5}{|l|}{ Population growth } \\
\hline \multicolumn{5}{|l|}{ Population growth rate } \\
\hline Temperature & 0.051 & 0.154 & 3 & $8.330^{* *}$ \\
\hline Prey density & 0.060 & 0.179 & 3 & $9.655^{* *}$ \\
\hline Temperature $\times$ prey density & 0.019 & 0.169 & 9 & $3.040^{* *}$ \\
\hline Error & 0.01 & 0.30 & 48 & \\
\hline
\end{tabular}

MS, mean square; SS, sum of squares; d.f., degrees of freedom; $F, F$ ratio.

*, Significant $(P<0.05),{ }^{* *}$, very significant $(P<0.01)$, ns, non-significant $(P>0.05)$.

at hatching of $A$. brightwelli fed $B$. angularis at 30 ind. $\mathrm{mL}^{-1}$ tended to be the longest, and the generation time increased with increasing $B$. angularis density. At $24^{\circ} \mathrm{C}$, both the average lifespan and the life expectancy at hatching increased with increasing prey density (Table 1).

Although it is the general trend that survival and developmental time of rotifers decreased with increasing temperature, the present results showed that the temperature effect on survival and developmental time of A. brightwelli depended on prey density. At 40 ind. $\mathrm{mL}^{-1}$ of $B$. angularis, both the average lifespan and the life expectancy at hatching of $A$. brightwelli did decrease with increasing temperature. However, at 10 and 20 ind. $\mathrm{mL}^{-1}$ of $B$. angularis, both the average lifespan and the life expectancy at hatching of $A$. brightwelli at 20,24 and $28^{\circ} \mathrm{C}$ were similar. At 30 ind. $\mathrm{mL}^{-1}$ of $B$. angularis, both the average lifespan and the life expectancy at hatching of A. brightwelli at 24 and $28^{\circ} \mathrm{C}$ were also similar. At all the four $B$. angularis densities, the generation time of $A$. brightwelli did not decrease with increasing temperature (Table 1). All those results stated above did not support the hypothesis that at all the tested prey levels, both the survival and the generation time of $A$. brightwelli decrease with increasing temperature, and might be attributed to the significant interaction between temperature and prey density.

The net reproductive rate of $A$. girodi fed $B$. calyciflorus at 2 ind. $\mathrm{mL}^{-1}$ or $B$. havanaensis at 1 ind. $\mathrm{mL}^{-1}$ was the lowest (Sarma et al., 2003), but that of $A$. girodi fed $A$. fissa increased with increasing prey density (Dumont and Sarma, 1995). In the present study, we found that the effect of prey density on the net reproductive rate of A. brightwelli depended on temperature. At 16 and $20^{\circ} \mathrm{C}$, $B$. angularis density did not affect the net reproductive rate of $A$. brightwelli. But at $24{ }^{\circ} \mathrm{C}$, the net reproductive rate of $A$. brightwelli fed $B$. angularis at 40 ind. $\mathrm{mL}^{-1}$ was higher than that at 10 and 20 ind. $\mathrm{mL}^{-1}$. At $28^{\circ} \mathrm{C}$, the net reproductive rate of $A$. brightwelli fed $B$. angularis at 10 ind. $\mathrm{mL}^{-1}$ was the lowest (Table 1). The results stated above supported hypothesis that whether a prey level is suitable for the reproduction of $A$. brightwelli depends on temperature, and the negative effect of the unsuitable food level becomes greater with increasing temperature. In addition, the effect of temperature on the net reproductive rate of $A$. brightwelli also depended on prey density. 


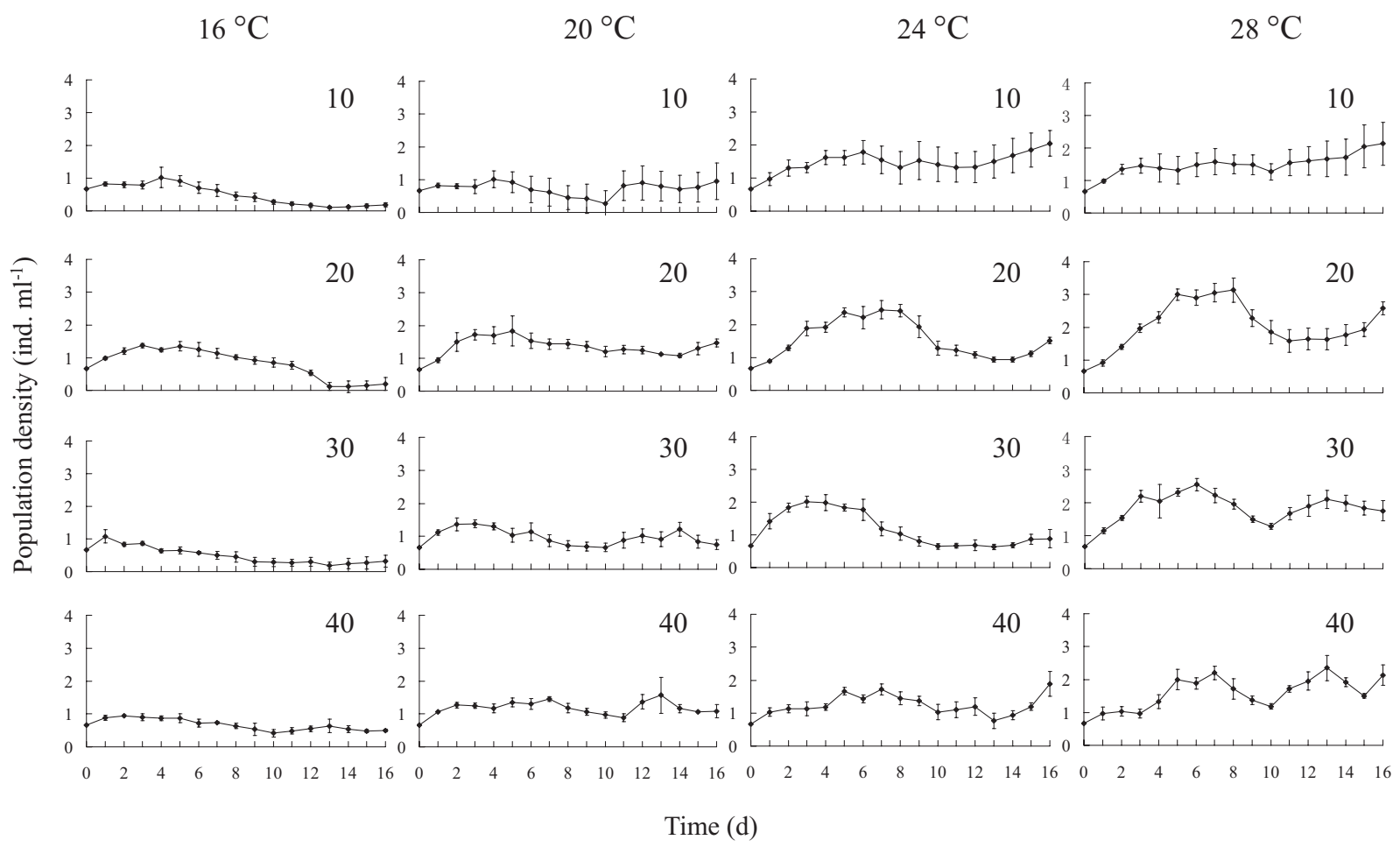

Fig. 2. Population growth curves of Asplanchna brightwelli cultured at four temperatures and prey $\left(\right.$ B. angularis, ind.mL $\left.{ }^{-1}\right)$ densities $($ mean $\pm \mathrm{SE})$.

At 10 and 20 ind. $\mathrm{mL}^{-1}$ of $B$. angularis, the net reproductive rate of $A$. brightwelli was higher at 16 and $20^{\circ} \mathrm{C}$ than at 24 and $28^{\circ} \mathrm{C}$. At 30 ind. $\mathrm{mL}^{-1}$ of $B$. angularis, the net reproductive rate of $A$. brightwelli was higher at 16 and $20^{\circ} \mathrm{C}$ than at $24^{\circ} \mathrm{C}$, and that at $28^{\circ} \mathrm{C}$ was not significantly different from that at 16 and $24^{\circ} \mathrm{C}$. The further increase in $B$. angularis density made the significant effect of temperature on the net reproductive rate disappeared (Table 1).

An organism usually utilizes its intake energy for survival, growth and reproduction. Because of the differences in the energetic costs of metabolism at different temperatures, the demand for intake energy for survival, growth and reproduction was lower at lower temperatures than at higher ones, which might be the reason for that at $20^{\circ} \mathrm{C}$, A. brightwelli fed 30 ind. $\mathrm{mL}^{-1}$ of $B$. angularis tended to have the longest lifespan and the highest reproductive rate; but at $24^{\circ} \mathrm{C}$, only 40 ind. $\mathrm{mL}^{-1}$ of $B$. angularis maximized the lifespan and the reproductive rate of A. brightwelli.

The data of net reproductive rate of $A$. brightwelli obtained in the present study were much lower than those reported for Asplanchna (e.g., 9-15 offspring female ${ }^{-1}$ lifespan $^{-1}$ for A. girodi; Dumont and Sarma, 1995), which might be attributed to the much lower prey biomass used here.

The intrinsic rate of population increase of $A$. girodi obtained from life-table demography increased with increasing prey (B. havanaensis or B. calyciflorus) availability in the medium (Sarma et al., 2003), but that of $A$. girodi was not significantly affected by $A$. fissa density (Dumont and Sarma, 1995). Similarly, in the present study, at 16 and $20^{\circ} \mathrm{C}, \mathrm{B}$. angularis density did not affect the intrinsic rate of population increase of $A$. brightwelli. At $24^{\circ} \mathrm{C}$, however, the intrinsic rate of population increase of $A$. brightwelli fed $B$. angularis at 40 ind. $\mathrm{mL}^{-1}$ was higher than that at 10 ind. $\mathrm{mL}^{-1}$. At $28^{\circ} \mathrm{C}$, the intrinsic rate of population increase of $A$. brightwelli fed $B$. angularis at 10 ind. $\mathrm{mL}^{-1}$ was the lowest. In addition, the present results showed that at 10 and 20 ind. $\mathrm{mL}^{-1}$ of B. angularis, the intrinsic rate of population increase of $A$. brightwelli at $20^{\circ} \mathrm{C}$ was the highest. At 30 and 40 ind. $\mathrm{mL}^{-1}$ of $B$. angularis, the intrinsic rate of population increase of A. brightwelli was not affected by temperature (Table 1).

The $r$ values in population growth studies of $A$. siebold $i$ Leydig fed B. havanaensis, B. rubens Ehrenberg, B. patulus Muller, B. macracanthus Jakubski or B. calyciflorus and A. brightwelli fed B. calyciflorus or A. fissa increased with increasing prey density (Sarma et al., 1998, 2002b; Nandini et al., 2003). Similarly, in the present study, at $28^{\circ} \mathrm{C}$, the population growth rate of $A$. brightwelli increased with increasing $B$. angularis density. However, at $24^{\circ} \mathrm{C}$, the population growth rate of $A$. brightwelli fed $B$. angularis at 30 and 40 ind. $\mathrm{mL}^{-1}$ was higher than that at 10 and 20 ind. $\mathrm{mL}^{-1}$. At 16 and $20^{\circ} \mathrm{C}$, the population growth rate of $A$. brightwelli was not affected by $B$. angularis density. In addition, the present results showed that at 10 and 40 ind. $\mathrm{mL}^{-1}$ of $B$. angularis, the population growth rate of $A$. brightwelli was not affected by temperature. At 20 ind. $\mathrm{mL}^{-1}$ of $B$. angularis, the population growth rate of A. brightwelli was higher at 16 and $20^{\circ} \mathrm{C}$ than at 24 and $28^{\circ} \mathrm{C}$. At 30 ind. $\mathrm{mL}^{-1}$ of $B$. angularis, the population 
growth rate of $A$. brightwelli was the highest at $24{ }^{\circ} \mathrm{C}$ (Table 1).

Generally, rotifers are opportunistic which own high population growth rates (Allan, 1976). Most herbivorous rotifers usually have $r$ values about 0.5 day $^{-1}$ (Sarma et al., 2001), but carnivorous genus may have $r$ values higher than 0.5 up to $1.5 \mathrm{day}^{-1}$. The $r$ values of $A$. girodi ranged from 0.09 to $1.51 \mathrm{day}^{-1}$ (Dumont and Sarma, 1995; Sarma et al., 2003), and those of A. sieboldi ranged from 0.07 to $0.43 \mathrm{day}^{-1}$ (Sarma et al., 2002a; Nandini et al., 2003). A. brightwelli had $r$ values of $0.22-1.01 \mathrm{day}^{-1}$ (Sarma et al., 1998). In the present study, the $r$ values of $A$. brightwelli ranged from 0.05 to 0.33 day $^{-1}$, and are in agreement with the range stated above for those Asplanchna species.

The $r$ values in population growth studies are generally smaller than those from life-table demography (Dumont and Sarma, 1995; Sarma et al., 2003). Identical results were obtained in the present study. Intrinsic rate of population increase is defined as the rate of increase per animal under specified physical conditions, in an unlimited environment where the effects of increasing density do not need to be considered (Birch, 1948), which might be the reason for that disparity between the two types of $r$ values.

In natural water bodies, the dynamics patterns of A. brightwelli population will be changed by climate changes, which will lead to community reorganizations and imply consequences for the functioning of ecosystems.

\section{Conclusion}

Temperature affected significantly all the life-table demographic parameters and the population growth rate obtained from the population growth study, prey density affected the generation time, the net reproductive rate, the intrinsic rate of population increase and the population growth rate, and the interaction between temperature and prey density affected the generation time and the population growth rate. At $20^{\circ} \mathrm{C}$ under $20-40$ ind.mL $\mathrm{m}^{-1}$ of $B$. angularis, A. brightwelli had higher population growth rates.

Acknowledgements. This work was supported by the Natural Science Foundation of China (grant numbers 31470015 and 31170395), Foundation of $\mathrm{PhD}$ Program of Ministry of Education of the People's Republic of China (grant no. 20093424110002), Natural Science Foundation for Young of Anhui Province (grant no. 1208085QC59) and Research Culture Funds of Anhui Normal University (2011rcpy041).

\section{References}

Allan J.D., 1976. Life history patterns in zooplankton. Am. Nat., 110, 165-180.

Arndt H., 1993. Rotifers as predators on components of the microbial web (bacteria, heterotrophic flagellates, ciliates) - a review. Hydrobiologia, 255/256, 231-246.
Birch L.C., 1948. The intrinsic rate of natural increase of an insect population. J. Anim. Ecol., 17, 15-26.

Conde-Porcuna J.M. and Declerck S., 1998. Regulation of rotifer species by invertebrate predators in a hypertrophic lake: selective predation on egg-bearing females and induction of morphological defences. Plank. Res., 20, 605-608.

Conde-Porcuna J.M. and Sarma S.S.S., 1995. Prey selection by Asplanchna girodi (Rotifera): the importance of prey defence mechanisms. Freshw. Biol., 33, 341-348.

Dumont H.J., 1977. Biotic factors in the population dynamics of rotifers. Arch. Hydrobiol. Beih, 8, 98-112.

Dumont H.J. and Sarma S.S.S., 1995. Demography and population growth of Asplanchna girodi (Rotifera) as a function of prey (Anuraeopsis fissa) density. Hydrobiologia, 306, 97-107.

Ejsmont-Karabin J., 1974. Studies on the feeding of planktonic polyphage Asplanchna priodonta Gosse (Rotatoria). Ekol. Pol., 26, 311-317.

Gilbert J.J., 1963. Mictic female production in rotifer Brachionus calyciflorus. J. Exp. Zool., 153, 113-124.

Guiset A., 1977. Stomach contents in Asplanchna and Ploesoma. Arch. Hydrobiol. Beih, 8, 126-129.

Iyer N. and Rao T.R., 1996. Responses of the predatory rotifer Asplanchna intermedia to prey species differing in vulnerability: laboratory and field studies. Freshwat. Biol., 36, 521-533.

Krebs C.J., 1985. Ecology: the Experimental Analysis of Distribution and Abundance. Harper \& Row, New York, $800 \mathrm{p}$.

Li S.-H., Zhu H., Xia Y.-Z., Yu M., Liu K., Ye Z. and Chen Y., 1959. The mass culture of unicellular green algae. Acta Hydrobiol. Sin., 4, 462-472.

Nandini S. and Sarma S.S.S., 1999. Effect of hunger level on the prey capture behavior, functional response and population growth of Asplanchna sieboldi (Rotifera). Freshwat. Biol., 42, 121-130.

Nandini S. and Sarma S.S.S., 2000. Life-table demography of four cladoceran species in relation to algal food (Chlorella vulgaris) density. Hydrobiologia, 491, 211-219.

Nandini S., Pérez-Chávez R. and Sarma S.S.S., 2003. The effect of prey morphology on the feeding behavior and population growth of the predatory rotifer Asplanchna sieboldi: a case study using five species of Brachionus (Rotifera). Freshwat. Biol., 48, 2131-2140.

Pianka E.R., 1988. Evolutionary Ecology (3rd edn), Harper \& Row, New York.

Poole R.W., 1974. An Introduction to Quantitative Ecology, McGraw-Hill, New York, 532 p.

Pourriot R., 1977. Food and feeding habits of the Rotifera. Arch. Hydrobiol. Beih., 8, 243-260.

Sarma S.S.S., 1993. Feeding responses of Asplanchna brightwelli (rotifera): laboratory and field studies. Hydrobiologia, 255/ 256, 275-282.

Sarma S.S.S., Dumont H.J. and Nandini S., 1998. Feeding preference and population growth of Asplanchna brightwelli (Rotifera) offered two non-evasive prey rotifers. Hydrobiologia, 361, 77-87.

Sarma S.S.S., Larios-Jurado P.S. and Nandini S., 2001. Effect of three food types on the population growth of Brachionus calyciflorus and Brachionus patulus (Rotifera: Brachionidae). Rev. Biol. Trop., 49, 75-82. 
Sarma S.S.S., Larios-Jurado P.S. and Nandini S., 2002a. Population growth of Asplanchna sieboldi fed two Brachionus spp. (Rotifera) raised on green alga and baker's yeast. Hydrobiologia, 467, 63-69.

Sarma S.S.S., Nandini S. and Gulati R.D., 2002b. Cost of reproduction in selected species of zooplankton (rotifers and cladocerans). Hydrobiologia, 481, 89-99.

Sarma S.S.S., Lucía Pavón-Meza E. and Nandini S., 2003. Comparative population growth and life table demography of the rotifer Asplanchna girodi at different prey (Brachionus calyciflorus and Brachionus havanaensis) (Rotifera) densities. Hydrobiologia, 491, 309-320.

Sarma S.S.S., Resendiz R.A.L. and Nandini S., 2011. Morphometric and demographic responses of brachionid prey (Brachionus calyciflorus Pallas and Plationus macracanthus (Daday) in the presence of different densities of the predator Asplanchna brightwellii (Rotifera: Asplanchnidae). Hydrobiologia, 662, 179-187.

Seoánes M. and Aguado A., 1995. Aguas residuales urbanas Tratamientos naturales de bajo costo y aprovechamiento, Mundi Prensa, Madrid, Spain, 368 p.
Urabe J., 1992. Midsummer succession of rotifer plankton in a shallow eutrophic pond. J. Plank. Res., 14, 851-866.

Verdone-Smith C. and Enesco H.E., 1982. The effect of temperature and of dietary restriction on lifespan and reproduction in the rotifer Asplanchna brightwelli. Exp. Gerontol., 17, 255-262.

Wen X.-L., Xi Y.-L., Qian F.-P., Zhang G. and Xiang X.-L., 2011a. Comprative comparison of rotifer community structure in five subtropical shallow lakes in East China: role of physical and chemical conditions. Hydrobiologia, 662, 303-316.

Wen X.-L., Xi Y.-L., Yang Y.-F., Zhang X.-A. and Zhang G., $2011 \mathrm{~b}$. Temperature is the key factor controlling population dynamics of Brachionus angularis in Lake Jinghu during summer and autumn. J. Freshw. Ecol., 26, 277-286.

Williamson C.E., 1983. Invertebrate predation of planktonic rotifers. Hydrobiologia, 104, 385-396.

Xie P., 2014. Comparative studies on the spatio-temporal dynamics of the community structure and the food guilds of rotifers in two lakes in Wuhu City, Anhui Province. Thesis for Master degree, Anhui Normal University. 